\title{
MENINGKATKAN PEMAHAMAN KONSEP MATERI MATEMATIKA SMP MENGGUNAKAN MODEL PEMBELAJARAN KOOPERATIF TIPE JIGSAW PADA MAHASISWA PRODI PENDIDIKAN MATEMATIKA UAD
}

\author{
Vita Istihapsari \\ Program Studi Pendidikan Matematika FKIP UAD \\ J1. Prof. Dr. Soepomo, S.H., Janturan, Warungboto, Umbulharjo, Yogyakarta \\ vita.istihapsari@pmat.uad.ac.id
}

\begin{abstract}
ABSTRAK
Tujuan penelitian ini adalah untuk meningkatkan kemampuan pemahaman konsep mahasiswa prodi pendidikan matematika Universitas Ahmad Dahlan pada materi-materi matematika SMP dengan memperbaiki praktik pembelajarannya. Penelitian ini merupakan penelitian tindakan kelas yang terdiri dari dua siklus dan melibatkan satu rombongan belajar mata kuliah Analisis Kurikulum Matematika SMP semester gasal tahun akademik 2016/2017. Siklus pertama fokus pada pembiasaan mahasiswa terhadap pembelajaran kooperatif tipe Jigsaw dan standar isi, sedangkan siklus kedua fokus pada pendalaman konsep-konsep materi matematika SMP. Hasil penelitian menunjukkan bahwa hanya 5,88\% mahasiswa tuntas pada pretest. Pada posttest siklus I, banyaknya mahasiswa yang tuntas mencapai $68,63 \%$. Sedangkan pada posttest II, banyaknya mahasiswa yang tuntas meningkat mencapai 80,39\%. Model pembelajaran kooperatif tipe Jigsaw memungkinkan mahasiswa mengeksplorasi konsep-konsep sesuai dengan pembagian materi secara lebih mendalam melalui diskusi kelompok ahli. Pada akhirnya, kelompok ahli tersebut kembali ke kelompok asal untuk saling membantu memahami materi secara keseluruhan. Simpulan penelitian ini adalah bahwa pembelajaran Jigsaw dapat memaksimalkan keaktifan siswa dalam mengumpulkan informasi, berdiskusi, dan saling membantu dalam belajar konsep-konsep matematika sehingga mampu meningkatkan pemahaman konsep mahasiswa.
\end{abstract}

Kata Kunci: Pemahaman konsep, Analisis kurikulum matematika SMP, Model pembelajaran kooperatif tipe Jigsaw.

\begin{abstract}
This research aims to enhance the ability of conceptual understanding of the mathematics education students in Ahmad Dahlan University towards the junior high school mathematics material by improving its practice. This research is a classroom action research which consists of two cycles and involved a class of students taking analysis of junior high school mathematics curriculum in the first semester of 2016/2017 academic year. The first cycle focused on the habituation of the students towards the implementation of Jigsaw type of cooperative learning model and the discussion of content standard of Indonesian curriculum, while the second cycle focused on the discussion of material in depth. The results suggest that the percentage of the students performed well in the pretest is only $5.88 \%$, in the posttest of the first cycle is $68.63 \%$, and in the posttest of the second cycle is $80.39 \%$. The Jigsaw type of cooperative learning model enable the students to explore mathematics concepts assigned to each group deeper through discussion in expert group. In the end, the member of expert groups would return to their initial group and help each other to understand all of the material. This research concludes that the Jigsaw type of cooperative learning model could optimize the students'
\end{abstract}


engagement in collecting information, discussing, and helping each other in understanding mathematics concepts such that it can improve the students' conceptual understanding.

Keywords: Conceptual understanding, Junior high school mathematics curriculum analysis, Jigsaw type of cooperative learning model.

\section{Pendahuluan}

Pendidikan yang baik dan unggul sangat bergantung pada profesionalisme, kinerja dan kompetensi gurunya. Banyak faktor yang menentukan kualitas pendidikan, namun guru tetap dipandang sebagai faktor penentu utama, karena guru yang memegang kendali pembelajaran, menentukan arah pencapaian tujuan pembelajaran, dan mengelola pembelajaran peserta didik. Untuk menghasilkan peserta didik berkualitas diperlukan guru yang berkualitas, memiliki kompetensi, dan dedikasi tinggi dalam menjalankan tugas profesionalnya (Amir, 2013; Kunandar, 2007; Jalal, 2007). Guru matematika yang berkualitas disiapkan sejak para kandidat guru belajar di jenjang perguruan tinggi. Para mahasiswa yang belajar di program studi pendidikan matematika Universitas Ahmad Dahlan Yogyakarta merupakan para calon guru yang harus memiliki kemampuan yang memadai agar mampu membelajarkan peserta didik dengan baik. Capaian pembelajaran mahasiswa dapat dilihat pada indikator kemampuan kognitif, psikomotor, dan afektif. Kemampuan kognitif yang harus dikuasai mahasiswa meliputi konsep, fakta, prosedur, dan prinsip ilmu pengetahuan terkait mata kuliah (Arifin, 2009). Dalam hal ini, para calon guru matematika harus memiliki pemahaman konsep matematika yang benar dan memadai.

Pemahaman konsep adalah suatu keadaan ketika mahasiswa diminta untuk memahami atau mengerti suatu ide (abstrak), gagasan, atau pandangan yang memungkinkan mahasiswa mampu mempertahankan, membedakan, memberi contoh, hingga menggeneralisasi objek sesuai dengan indikator-indikator tertentu (Arikunto, 2009; Wardhani, 2008; Prawiradilaga, 2007; Arifin, 2009). Pemahaman konsep matematika juga dapat dipandang sebagai proses membangun makna terhadap suatu objek matematika (Sierpinska, 1990) serta melibatkan proses membangun hubungan antara pengetahuan yang sudah ada dengan pengetahuan baru berkaitan dengan suatu objek matematika (Hiebert \& Lefevre, dalam Long, 2005).

Peneliti menemukan bahwa pemahaman konsep matematika para mahasiswa masih rendah. Hal ini diketahui dari pencapaian mahasiswa pada mata 
kuliah Analisis Kurikulum Matematika SLTA, di mana rata-rata nilai ujian mahasiswa di kelas tersebut hanya 46,53. Peneliti menemukan bahwa banyak mahasiswa yang menunjukkan kesalahan konsep ketika mengajarkan materi matematika SLTA tersebut. Berdasarkan diskusi dengan tim dosen pengampu, kesalahan konsep tersebut disebabkan oleh rendahnya pemahaman konsep mahasiswa pada materi yang mendasarinya, yaitu konsep materi kurikulum matematika SMP, sehingga treatment perlu dilakukan sejak perkuliahan Analisis Kurikulum Matematika SMP.

Metode pembelajaran yang biasa digunakan oleh dosen pengampu adalah reciprocal teaching. Reciprocal teaching mengacu pada kegiatan pengajaran di mana siswa menjadi guru pada suatu kelompok, kemudian guru membimbing diskusi (Palincsar \& Brown, 1984). Metode ini mengharuskan mahasiswa mencari materi yang relevan untuk dipaparkan di depan kelas secara berkelompok, kemudian dosen pengampu membimbing diskusi. Walaupun metode ini mampu membuat mahasiswa aktif berupaya mencari materi, metode ini memiliki kelemahan yaitu mahasiswa cenderung hanya menguasai materi yang diamanahkan kepada kelompoknya saja. Peneliti memandang perlunya inovasi pembelajaran yang memungkinkan mahasiswa fokus dalam mencari materi AdMathEdu | Vol.7 No.1 | Juni 2017 yang relevan sekaligus saling membantu untuk membuat seluruh mahasiswa di kelompoknya memahami keseluruhan materi. Oleh karena itu, peneliti menerapkan model pembelajaran kooperatif tipe Jigsaw pada kelas tersebut.

Model pembelajaran kooperatif tipe Jigsaw merupakan model pembelajaran yang memungkinkan mahasiswa membentuk kelompok belajar yang heterogen sebagai tim asal. Selanjutnya mahasiswa dikondisikan membentuk tim ahli yang bertugas untuk menemukan konsep-konsep sesuai dengan pembagian materi. Pada akhirnya, tim ahli tersebut akan kembali ke kelompok asal untuk saling membantu memahami materi yang telah didiskusikan oleh tim ahli (Widyantini, 2006). Metode Jigsaw pertama kali dikenalkan oleh Aronson (dalam Kordaki \& Siempos, 2010) dan diklaim mampu membangun keterampilan interpersonal serta meningkatkan partisipasi peserta didik dalam pembelajaran. Kunci keberhasilan Jigsaw terletak pada diberikannya tanggung jawab kepada setiap anggota kelompok ahli untuk mentransfer informasi pada kelompokkelompok asalnya (Karacop, 2017).

\section{Metode Penelitian}

Penelitian ini merupakan Penelitian Tindakan Kelas (PTK) yang terdiri dari dua siklus tindakan. Siklus pertama fokus pada Meningkatkan... (Vita Istihapsari) 
pengenalan pembelajaran kooperatif tipe Jigsaw dan pengenalan materi standar isi kurikulum SMP, sedangkan siklus kedua fokus pada pendalaman materi. Peneliti mengampu satu rombongan belajar mata kuliah Analisis Kurikulum Matematika SMP semester gasal tahun akademik 2016/2017 dengan peserta kuliah 51 mahasiswa. Prosedur kerja penelitian tindakan kelas mengacu pada model yang salah satunya dikemukakan oleh Arikunto (2006) pada Gambar 1 berikut.

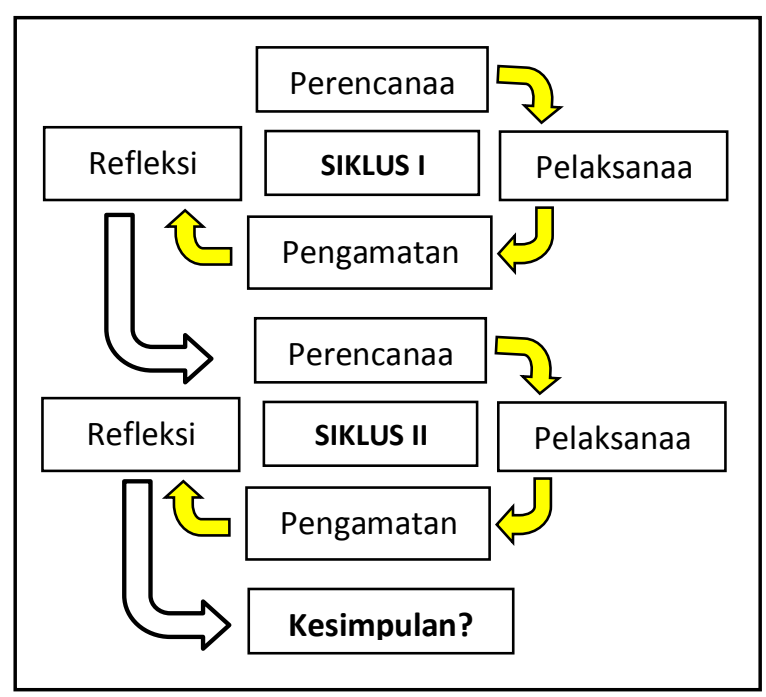

Gambar 1 Skema Pelaksanaan Siklus Tindakan

\section{Hasil dan Pembahasan}

\section{Pratindakan}

Peneliti mengukur kemampuan awal mahasiswa dengan mengadakan pretest untuk materi matematika SMP. Pretest memiliki kedudukan yang sangat penting sebagai pijakan awal dan pembanding apakah setelah tindakan

Meningkatkan... (Vita Istihapsari) terjadi perubahan pada variabel yang diamati. Hasil pretest menunjukkan bahwa rata-rata nilai pretest adalah 40,93 dengan persentase ditunjukkan pada Tabel 1 berikut.

Tabel 1 Hasil Pretest

\begin{tabular}{cccc}
\hline $\mathbf{N}$ & Kategori & Jumlah & $\begin{array}{c}\text { Persenta } \\
\text { se }\end{array}$ \\
\hline 1 & $\begin{array}{l}\text { Tuntas, nilai } \geq 65 \\
\text { Tidak tuntas, } \\
2\end{array}$ & 3 & $5,88 \%$ \\
& $\begin{array}{c}\text { nilai }<65 \\
\text { Jumlah }\end{array}$ & 48 & $94.12 \%$ \\
& 51 & $100 \%$ \\
\hline
\end{tabular}

Berdasarkan Tabel 1 dapat dilihat bahwa banyaknya mahasiswa yang mendapat nilai minimal 65 hanya 5,88\% sedangkan selebihnya $94,12 \%$ mahasiswa belum mencapai nilai minimal yang disyaratkan lulus, yaitu 65 atau kategori B.

\section{Siklus I \\ Perencanaan}

Kegiatan siklus I diawali dengan perencanaan yang meliputi: (1) menelaah hasil pretest untuk mengetahui kelemahan konsep mahasiswa, (2) menyusun perangkat pembelajaran dan instrumen penelitian, serta (3) berkolaborasi dengan teman sejawat untuk melakukan observasi dan dokumentasi. Depdiknas (dalam Duha, 2012) menjelaskan bahwa penilaian kemampuan pemahaman konsep sebagai 
hasil belajar matematika didasarkan pada indikator-indikator meliputi:

menyatakan ulang sebuah konsep; (2) mengklasifikasikan objek menurut sifat tertentu (sesuai dengan konsep); (3) memberi contoh dan non contoh dari konsep; (4) menyajikan konsep dalam bentuk representasi matematika; mengembangkan syarat perlu ayau syarat cukup suatu konsep; (6) menggunakan, memanfaatkan dan memilih prosedur atau operasi tertentu; dan (7) mengaplikasikan konsep. Peneliti menemukan bahwa secara umum mahasiswa menunjukkan kelemahan pada aspek menggunakan, memanfaatkan dan memilih prosedur operasi tertentu. Salah satu temuan yang mengindikasikan kesalahan konsep disajikan pada Gambar 2 berikut.

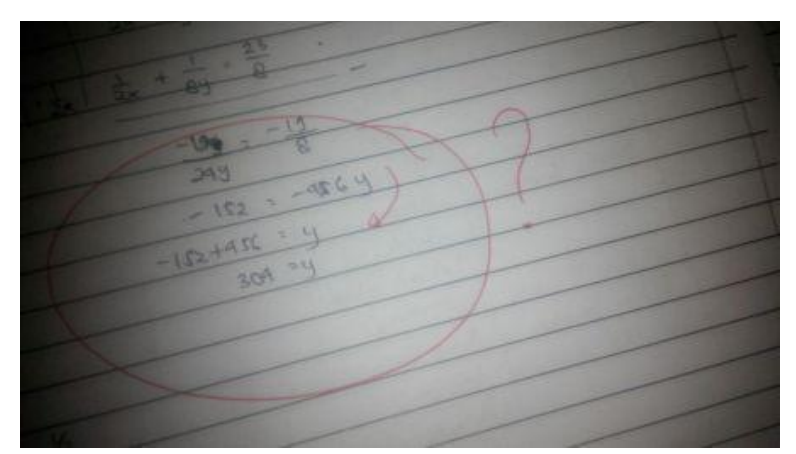

Gambar 2 Kesalahan konsep pada penerapan algoritma

Pada Gambar 2, terlihat bahwa mahasiswa menulis:

$$
\begin{gathered}
-152=-456 y \\
-152+456=y \\
304=y
\end{gathered}
$$

Ekspresi di atas menunjukkan bahwa mahasiswa tersebut tidak memahami atau melupakan prosedur mengenai menambah atau mengali kedua ruas persamaan dengan unsur yang sama. Mahasiswa tersebut dapat diasumsikan memiliki kesalahan konsep "perpindahan ruas" alih-alih yang seharusnya yaitu "menambah atau mengali kedua ruas persamaan dengan unsur yang sama”. Selanjutnya, mahasiswa tersebut dapat dipastikan melakukan kekeliruan "menyamakan perpindahan ruas penjumlahan dengan perkalian”. Prihandoko (2005) menyebutkan bahwa sebuah kesamaan $\mathrm{p}=\mathrm{q}$ tidak akan berubah apabila pada kedua ruas ditambah, dikurangi, dikalikan, atau dibagi dengan bilangan yang sama.

Ekspresi di atas menunjukkan bahwa mahasiswa tersebut tidak memahami atau melupakan prosedur mengenai menambah atau mengali kedua ruas persamaan dengan unsur yang sama. Mahasiswa tersebut dapat diasumsikan memiliki kesalahan konsep "perpindahan ruas" alih-alih yang seharusnya yaitu "menambah atau mengali kedua ruas persamaan dengan unsur yang sama". Selanjutnya, mahasiswa tersebut dapat dipastikan melakukan kekeliruan "menyamakan perpindahan ruas penjumlahan dengan perkalian". Prihandoko (2005) menyebutkan bahwa

$$
\text { Meningkatkan... (Vita Istihapsari) }
$$


sebuah kesamaan $\mathrm{p}=\mathrm{q}$ tidak akan berubah apabila pada kedua ruas ditambah, dikurangi, dikalikan, atau dibagi dengan bilangan yang sama.

Selanjutnya, peneliti mendiskusikan perangkat pembelajaran yang akan digunakan untuk menerapkan tindakan meliputi silabus dan satuan acara perkuliahan, serta instrumen pengamatan pembelajaran dengan teman sejawat. Diskusi tersebut sekaligus memvalidasi perangkat yang akan digunakan dalam penelitian.

\section{Pelaksanaan}

Pelaksanaan tindakan pada siklus I dilaksanakan dalam 2 kali pertemuan, tiap pertemuan berdurasi 3 x 50 menit ( $3 \mathrm{SKS}$ ). Adapun kegiatan yang dilakukan selama proses pembelajaran dapat dijabarkan sebagai berikut.

\section{Pertemuan I}

\section{Kegiatan Pendahuluan}

1. Dosen pengampu membuka perkuliahan dengan salam dan mengajak mahasiswa untuk berdoa demi kelancaran perkuliahan;

2. Dosen pengampu menyampaikan tujuan perkuliahan, yaitu: (1) mereviu konsep-konsep materi matematika SMP berdasarkan standar isi Kurikulum 2013, (2) memperoleh informasi gambaran kemampuan pemahaman konsep mahasiswa mengenai materi matematika SMP melalui pretest, (3) menjelaskan prosedur pembelajaran dengan menggunakan model pembelajaran Jigsaw.

3. Dosen pengampu memberikan motivasi dan apersepsi kepada mahasiswa melalui serangkaian kegiatan tanya jawab mengenai: (1) pentingnya memahami konsep secara benar, yaitu dengan mengingatkan kembali kapita selekta konsep sederhana di SMP yang sering dilupakan oleh mahasiswa, misalnya perbedaan penggunaan istilah "angka" dengan "bilangan", "segitiga" dengan "bidang segitiga", dan seterusnya; dan (2) pentingnya implementasi pembelajaran inovatif seperti model pembelajaran kooperatif tipe Jigsaw.

\section{Kegiatan Inti}

4. Dosen pengampu memaparkan singkat ruang lingkup materi matematika SMP yang diatur pada Standar Isi dan KI/KD Kurikulum 2013 dengan menggunakan media power point.

5. Dosen pengampu memberikan pretest.

6. Dosen pengampu menjelaskan prosedur pelaksanaan model pembelajaran kooperatif tipe Jigsaw dan mensimulasikannya.

AdMathEdu | Vol.7 No.1 | Juni 2017 
7. Tahap 1 Jigsaw: Pembentukan kelompok asal. Dosen pengampu membagi 51 mahasiswa peserta kuliah menjadi 5 kelompok, dengan setiap kelompok terdiri dari 10-11mahasiswa secara acak dengan cara mengundi. Pengacakan dengan undian tersebut diharapkan dapat mengelompokkan mahasiswa ke dalam kelompok heterogen dengan kemampuan yang berbeda-beda baik tingkat kemampuan tinggi, sedang dan rendah serta dimungkinkan anggota kelompok berasal dari ras, budaya, suku yang berbeda serta kesetaraan gender. Kelompok ini disebut kelompok asal.

8. Tahap 2 Jigsaw: Pembelajaran pada kelompok asal. Dosen pengampu membagi materi kepada setiap mahasiswa secara acak dengan undian.Banyaknya anggota dalam kelompok asal sesuai dengan banyaknya topik materi yang dipelajari, yaitu: (1) barisan bilangan, (2) relasi dan fungsi, (3) himpunan, (4) lingkaran, (5) perbandingan, (6) persamaan linier satu variabel, (7) prisma, (8) segiempat, (9) segitiga, dan (10) statistika dan peluang. Mahasiswa diberi penugasan untuk mengumpulkan informasi terkait materi masing-masing dan mulai merancang sub-sub topic yang akan dicari, meliputi: (1) definisi, (2) sifat- sifat, (3) contoh dan non contoh, (4) representasi matematis, (5) syarat cukup dan syarat perlu, prosedur/operasi, dan (7) penerapan konsep dalam pemecahan masalah.

9. Tahap 3 Jigsaw: Pembentukan kelompok ahli. Dosen pengampu membimbing mahasiswa untuk membentuk kelompok ahli dengan cara mahasiswa dengan topik materi yang sama membentuk kelompok masing-masing.

\section{Tahap 4 Jigsaw:Diskusi kelompok} ahli. Kelompok ahli berdiskusi untuk menyusun strategi mendapatkan materi yang lengkap dan memahaminya, serta merencnakan bagaimana cara menyampaikan kepada kelompok asal.

\section{Kegiatan Penutup}

11. Dosen membimbing mahasiswa untuk menyimpulkan materi perkuliahan, yaitu: (1) ruang lingkup materi matematika SMP, (2) pentingnya pemahaman konsep materi-materi tersebut, dan (3) topik yang menjadi tanggung jawab masing-masing mahasiswa untuk dikaji.

12. Dosen memberikan umpan balik berupa konfirmasi atas simpulan yang disampaikan oleh mahasiswa.

13. Dosen memberikan tindak lanjut berupa penugasan, yaitu meneruskan diskusi kelompok ahli di luar pertemuan tatap muka, lalu Meningkatkan... (Vita Istihapsari) 
mengirimkan hasil diskusinya ke dosen melalui email.

14. Dosen menyampaikan rencana pertemuan berikutnya, yaitu melanjutkan tahapan pembelajaran Jigsaw.

15. Dosen menutup perkuliahan dengan salam dan mengajak mahasiswa bersyukur atas kelancaran jalannya perkuliahan.

Pertemuan II

\section{Kegiatan Pendahuluan}

1. Dosen pengampu membuka perkuliahan dengan salam dan mengajak mahasiswa untuk berdoa demikelancaran perkuliahan;

2. Dosen pengampu menyampaikan tujuan perkuliahan, yaitu: melanjutkan tahapan pembelajaran Jigsaw, (2) memperoleh informasi gambaran kemampuan pemahaman konsep mahasiswa mengenai materi matematika SMP setelah diberi tindakan berupa pembelajaran Jigsaw melalui posttest.

3. Dosen pengampu memberikan motivasi dan apersepsi kepada mahasiswa melalui serangkaian kegiatan tanya jawab mengenai: (1) langkah-langah pembelajaran Jigsaw yang sudah berjalan dan apa yang masih harus dilaksanakan; dan (2) apakah mahasiswa menemukan hal-hal baru dari konsep-konsep yang sudah didiskusikan di luar perkuliahan dengan kelompok ahli.

\section{Kegiatan Inti}

\section{Tahap 5 Jigsaw: Diskusi kelompok} asal. Dosen pengampu mengarahkan mahasiswa untuk berkelompok sesuai dengan kelompok asal mereka, serta mulai berdiskusi menyampaikan hasil diskusi kelompok ahli ke kelompok asal.

5. Tahap 6 Jigsaw:Diskusi kelas. Setiap kelompok asal mempresentasikan salah satu topik yang dipelajari, dipilih yang paling esensial atau yang sering ditemui kesalahan dalam pembelajaran sehari-hari. Salah satu kelompok yang lain diberi kesempatan untuk memberi tanggapan. Dosen pengampu memberikan umpan balik pada materi yang dipresentasikan.

\section{Kegiatan Penutup}

6. Tahap 7 Jigsaw: Kuis. Dosen pengampu memberikan posttest siklus I

7. Tahap 8 Jigsaw: Pemberian penghargaan kelompok. Dosen pengampu memberikan penghargaan pada kelompok berdasarkan keaktifan anggota kelompok dalam diskusi dan presentasi kelompok asal.

AdMathEdu | Vol.7 No.1 | Juni 2017 
8. Dosen pengampu menutup perkuliahan dengan doa dan salam.

\section{Observasi}

Observasi bertujuan untuk mengukur keterlaksanaan pembelajaran pada siklus I. Hasil observasi menunjukkan bahwa $\quad 62,5 \% \quad$ langkah-langkah pembelajaran dilaksanakan dengan baik. Pengamat juga menemukan beberapa hal yang harus menjadi bahan perbaikan pertemuan berikutnya, di antaranya adalah: (1) pemakaian gawai yang belum optimal untuk mencari materi dan (2) suasana kelas yang belum kondusif sebagaimana disajikan pada Gambar 3 berikut.

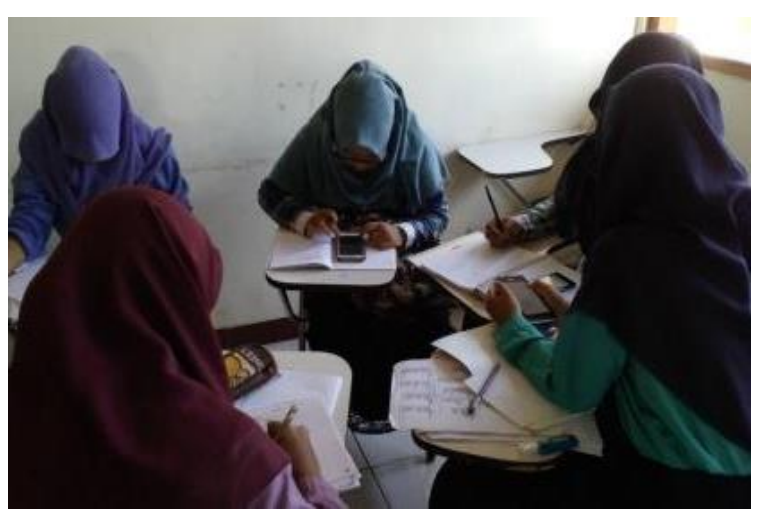

(a)

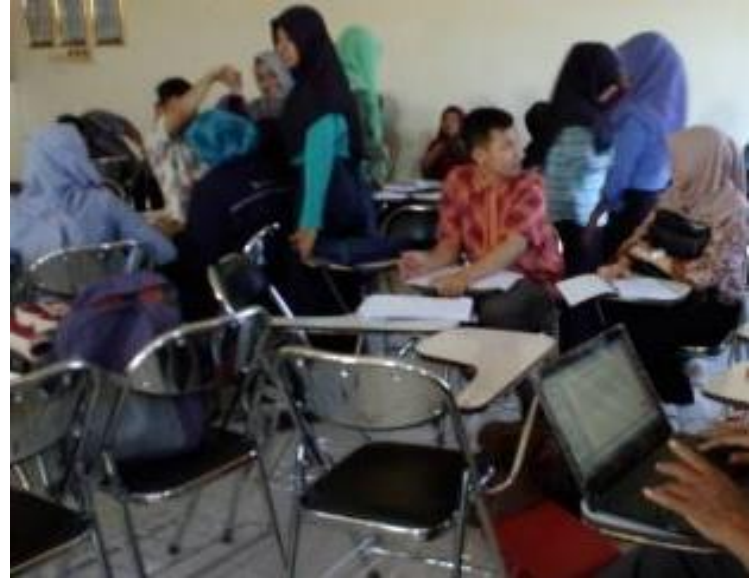

(b)

Gambar 3 Pemakaian gadget yang belum optimal untuk mencari materi (a) dan mahasiswa masih cederung belum dapat belajar dengan kondusif (b)

Sedangkan hasil posttest siklus I diperoleh rata-rata kemampuan pemahaman konsep mahasiswa sebesar 67,16 dan persentase ketuntasan belajar disajikan pada Tabel 2 berikut.

Tabel 2 Hasil Postest I

\begin{tabular}{llll}
\hline $\begin{array}{l}\text { N } \\
\text { o }\end{array}$ & Kategori & Jumlah & $\begin{array}{l}\text { Persenta } \\
\text { se }\end{array}$ \\
\hline 1 & Tuntas, nilai $\geq 65$ & 35 & $68,63 \%$ \\
\hline $\begin{array}{l}\text { Tidak } \\
\text { nilai }<65\end{array}$ & tuntas, & $31.37 \%$ \\
\hline Jumlah & 51 & 51 \\
\hline
\end{tabular}

Ditinjau dari hasil pekerjaan mahasiswa pada posttest I, peneliti menemukan kesalahan umum mahasiswa pada aspek menuliskan representasi 
matematis. Salah satunya disajikan pada Gambar 4 berikut.

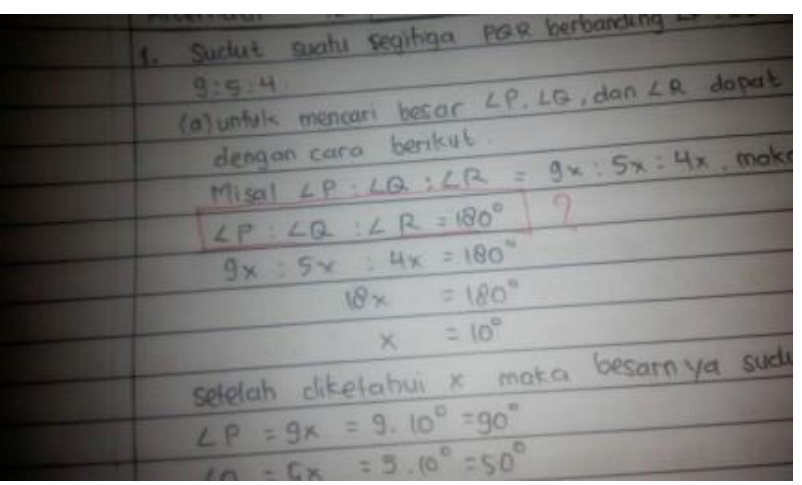

Gambar 4 Kekeliruan penulisan representasi matematis

Pada gambar tersebut, diperoleh gambaran kesalahan mahasiswa dalam menulis perbandingan sudut dalam segitiga.

$$
\angle P: \angle Q: \angle R=180^{\circ}
$$

Jelas hal tersebut merupakan kesalahan penulisan, karena yang dimaksud adalah bahwa $\angle P: \angle Q: \angle R=$ $9: 5: 4$, dengan $\angle P+\angle Q+\angle R=180^{\circ}$. Kesalahan yang dicontohkan di atas adalah kesalahan dalam representasi matematika. Representasi matematika merupakan salah satu dari tujuh kemampuan fundamental yang harus dimiliki oleh siswa/mahasiswa dalam literasi matematika. Kemampuan ini memungkinkan siswa untuk menuliskan permasalahan dalam kalimat matematika yang tepat sehingga pemecahan masalah dapat dilakukan dengan tepat pula (OECD, 2013).

\section{Refleksi}

Berdasarkan hasil dari observasi yang dikumpulkan, peneliti dapat merefleksi diri sebagai berikut. Alokasi waktu perkuliahan dengan tingkat kompleksitas materi yang cukup banyak tidak cukup untuk melaksanakan pembelajaran kooperatif tipe Jigsaw secara utuh dalam satu pertemuan. Hal ini juga dipicu oleh beberapa mahasiswa yang datang terlambat sehingga dosen pengampu harus mengulangi beberapa penjelasan yang terlewatkan. Selain itu, keterlambatan beberapa mahasiswa tersebut juga menghambat proses pembentukan kelompok. Rekomendasi dari kegiatan refleksi adalah dosen pengampu harus menekankan kepada mahasiswa agar tidak terlambat masuk kuliah pada pertemuan berikutnya dan memberi mereka tanggung jawab penugasan yang akan diperiksa di awal pertemuan.

Mahasiswa prodi Pendidikan Matematika UAD belum terbiasa membawa laptop sebagai bagian dari keseharian mereka, sehingga dosen pengampu tidak dapat mengkondisikan mahasiswa untuk mencari informasi dari sumber internet menggunakan fasilitas wifi yang tersedia. Mahasiswa beralasan bahwa 
koneksi internet yang lambat dan biasanya perkuliahan tidak membutuhkan laptop. Rekomendasi dari kegiatan refleksi adalah dosen pengampu menginstruksikan mahasiswa untuk selalu membawa laptop pada pertemuan berikutnya dan menggunakan thetering personal wifi dari smartphone masing-masing, mengingat setiap mahasiswa memiliki smartphone dengan paket data yang rata-rata memadai.

Berkaitan dengan pelaksanaan pembelajaran Jigsaw, mahasiswa mengaku pernah dijelaskan mengenai langkahlangkah pembelajaran tersebut tetapi belum terbiasa mempraktikkan, sehingga terkadang mahasiswa terlihat kebingungan mengenai apa yang harus dilakukan pada tahapan-tahapan Jigsaw. Rekomendasi dari kegiatan refleksi adalah bahwa dosen pengampu harus mengingatkan kembali dengan instruksi yang lebih jelas mengenai apa yang harus dilakukan pada setiap tahapan Jigsaw.

Permasalahan alokasi waktu juga berdampak pada kurangnya waktu yang tersedia untuk diskusi kelas. Pertanyaan dari mahasiswa kurang tergali dengan baik padahal aspek bertanya ini menjadi modal penting untuk menentukan apakah mahasiswa telah memahami konsep yang dipelajari. Rekomendasi dari kegiatan refleksi adalah bahwa dosen pengampu perlu merumuskan strategi diskusi kelas yang lebih mampu menggali pemahaman konsep dari mahasiswa.

\section{Siklus II \\ Perencanaaan}

Kegiatan perencenaan pada siklus II merupakan tindak lanjut refleksi siklus I, yaitu dengan (1) mengkaji hasil refleksi siklus I dan mencermati hal-hal yang direkomendasikan, dan (2) menyusun atau memperbaiki satuan acara perkuliahan dan instrumen penelitian sesuai dengan rekomendasi pada fase refleksi siklus I.

\section{Pelaksanaan}

Pelaksanaan tindakan pada siklus II dilaksanakan dalam 2 kali pertemuan, tiap pertemuan berdurasi 3 x 50 menit ( $3 \mathrm{SKS}$ ). Adapun kegiatan yang dilakukan selama proses pembelajaran dapat dijabarkan sebagai berikut.

\section{Pertemuan I}

\section{Kegiatan Pendahuluan}

1. Dosen pengampu membuka perkuliahan dengan salam dan mengajak mahasiswa untuk berdoa demi kelancaran perkuliahan.

2. Dosen pengampu menyampaikan tujuan perkuliahan, yaitu: memperdalam konsep-konsep materi matematika SMP sesuai dengan pembagian materi pada siklus I, (2) memperbaiki konsep-konsep yang masih keliru sesuai dengan hasil diskusi pada siklus I.

Meningkatkan... (Vita Istihapsari) 
3. Dosen pengampu memberikan motivasi dan apersepsi kepada mahasiswa melalui serangkaian kegiatan tanya jawab mengenai: (1) beberapa klarifikasi atas kekeliruan pemahaman konsep yang terjadi pada pembelajaran siklus I; dan perbaikan pembelajaran hasil refleksi siklus I, antara lain: ketidaksiapan mahasiswa dalam mencari informasi menggunakan laptop dan koneksi internet, pembiasaan diri pada pembelajaran Jigsaw, dan alokasi waktu diskusi kelas yang harus ditambahkan.

\section{Kegiatan Inti}

4. Tahap 1 Jigsaw: Pembentukan kelompok asal. Dosen pengampu mengisntruksikan kepada mahasiswa untuk berkelompok sama dengan kelompok asal pada pertemuan sebelumnya.

5. Tahap 2 Jigsaw: Pembelajaran pada kelompok asal. Dosen pengampu menginstruksikan kepada setiap mahasiswa untuk mencermati jatah materi masing-masing sesuai pembagian materi pada siklus I. Mahasiswa diminta untuk memperbaiki konsep-konsep yang keliru hasil diskusi pada pertemuan sebelumnya.
6. Tahap 3 Jigsaw: Pembentukan kelompok ahli. Dosen pengampu membimbing mahasiswa untuk membentuk kelompok ahli dengan cara mahasiswa dengan topik materi yang sama membentuk kelompok masing-masing.

7. Tahap 4 Jigsaw:Diskusi kelompok ahli. Kelompok ahli berdiskusi untuk mematangkan materi yang diperoleh.

8. Tahap 5 Jigsaw: Diskusi kelompok asal. Dosen pengampu mengarahkan mahasiswa untuk berkelompok sesuai dengan kelompok asal mereka, serta mulai berdiskusi menyampaikan hasil diskusi kelompok ahli ke kelompok asal. Dalam diskusi tersebut, setiap kelompok menyiapkan pertanyaan untuk dilontarkan ke kelompok yang lain. Pertanyaan tersebut akan digunakan untuk diskusi kelas.

9. Tahap 6 Jigsaw: Diskusi kelas. Kegiatan diskusi kelas disetting menjadi permainan tanya jawab. Setiap kelompok asal diberi kesempatan untuk menyampaikan pertanyaan rebutan untuk dijawab oleh kelompok lain. Poin diberikan kepada kelompok yang bisa menjawab dengan benar dan diberikan kesempatan untuk memberi pertanyaan berikutnya.

Kegiatan Penutup

AdMathEdu | Vol.7 No.1 | Juni 2017 
10. Dosen membimbing mahasiswa untuk menyimpulkan materi perkuliahan, yaitu pendalaman materi matematika SMP.

11. Dosen memberikan umpan balik berupa konfirmasi atas simpulan yang disampaikan oleh mahasiswa.

12. Dosen memberikan tindak lanjut berupa penugasan, yaitu belajar mandiri terkait materi yang dipelajari secara keseluruhan.

13. Dosen menyampaikan rencana pertemuan berikutnya, yaitu melakukan postest.

14. Dosen menutup perkuliahan dengan salam dan mengajak mahasiswa bersyukur atas kelancaran jalannya perkuliahan.

Pertemuan II

\section{Kegiatan Pendahuluan}

1. Dosen pengampu membuka perkuliahan dengan salam dan mengajak mahasiswa untuk berdoa demikelancaran perkuliahan;

2. Dosen pengampu menyampaikan tujuan perkuliahan, yaitu: melanjutkan tahapan pembelajaran Jigsaw, (2) memperoleh informasi gambaran kemampuan pemahaman konsep mahasiswa mengenai materi matematika SMP setelah diberi tindakan berupa pembelajaran Jigsaw melalui posttest.
3. Dosen pengampu memberikan motivasi dan apersepsi kepada mahasiswa melalui serangkaian kegiatan tanya jawab mengenai: (1) langkah-langah pembelajaran Jigsaw yang sudah berjalan dan apa yang masih harus dilaksanakan; dan (2) apakah mahasiswa menemukan hal-hal baru dari konsep-konsep yang sudah didiskusikan di luar perkuliahan dengan kelompok ahli.

\section{Kegiatan Inti}

4. Tahap 6 Jigsaw:Diskusi kelas (lanjutan). Mahasiswa diberi kesempatan untuk bertanya materi yang belum jelas. Dosen pengampu memberikan umpan balik.

\section{Kegiatan Penutup}

5. Tahap 7 Jigsaw: Kuis. Dosen pengampu memberikan posttest siklus II

6. Tahap 8 Jigsaw: Pemberian penghargaan kelompok. Dosen pengampu memberikan penghargaan pada kelompok berdasarkan keaktifan anggota kelompok dalam game dan tanya jawab kelompok asal.

7. Dosen pengampu menutup perkuliahan dengan doa dan salam. 
Observasi

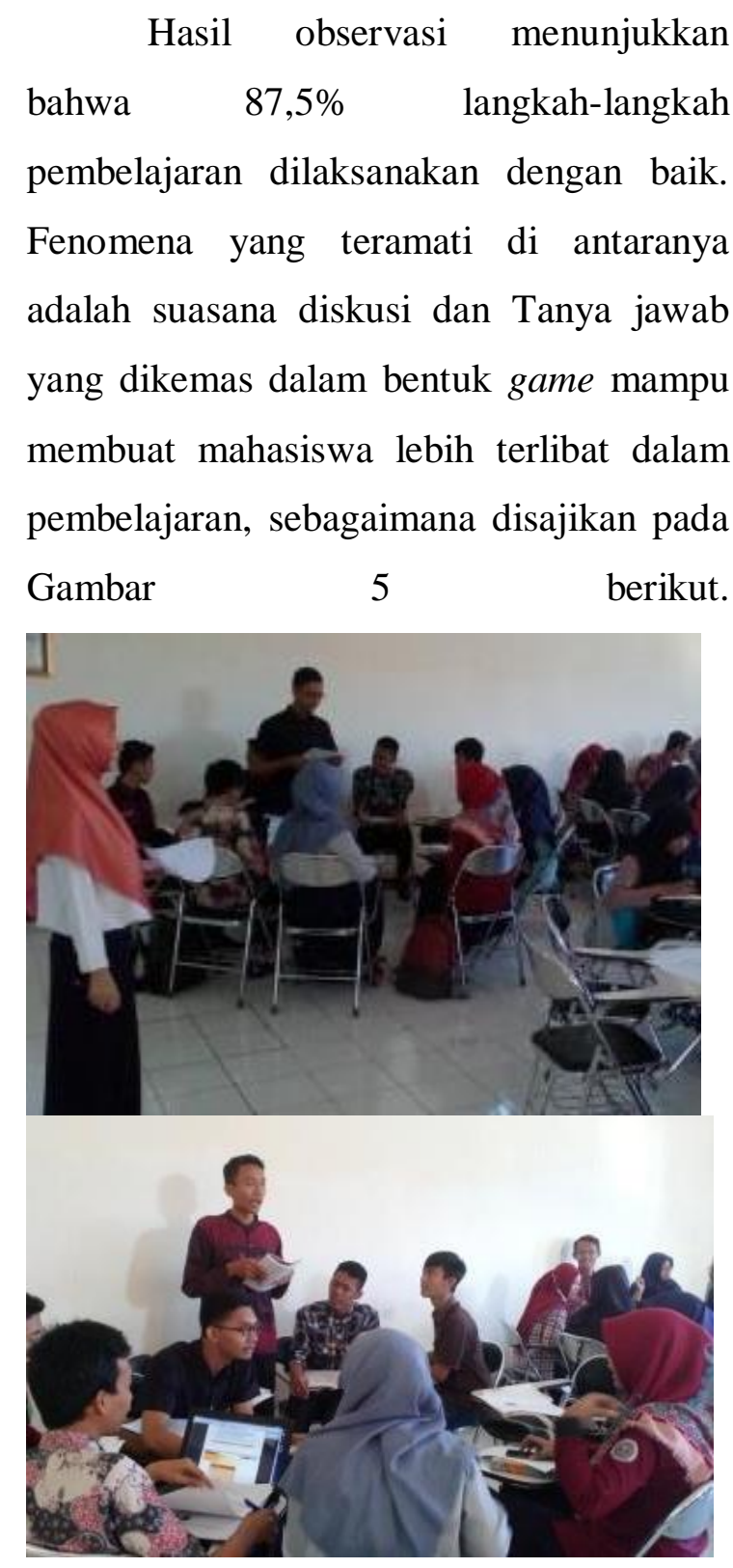

Gambar 5 Proses game tanya jawab pada fase diskusi kelas Siklus II

Selain itu, hasil posttest siklus II diperoleh rata-rata kemampuan pemahaman konsep mahasiswa sebesar 77,65 dan persentase ketuntasan belajar disajikan pada Tabel 3 berikut.

Meningkatkan... (Vita Istihapsari)
Tabel 3 Hasil Postest II

\begin{tabular}{|c|c|c|}
\hline Kategori & Jumlah & $\begin{array}{c}\text { Persenta } \\
\text { se }\end{array}$ \\
\hline 1 Tuntas, nilai $\geq 65$ & 41 & $80,39 \%$ \\
\hline $\begin{array}{l}\text { Tidak tuntas, } \\
\text { nilai }<65\end{array}$ & 10 & $19.61 \%$ \\
\hline Jumlah & 51 & 51 \\
\hline
\end{tabular}

\section{Refleksi}

Berdasarkan hasil dari observasi yang dikumpulkan, peneliti dapat merefleksi diri sebagai berikut. Alokasi waktu perkuliahan yang terbatas telah berhasil diatasi dengan dua cara, yaitu: (1) memaksimalkan proses belajar kelompok ahli di luar pertemuan melalui penugasan mahasiswa, dan (2) mengemas kegiatan diskusi kelas dengan game tanya jawab yang menarik. Kegiatan tersebut juga menggali pemahaman konsep mahasiswa dengan lebih mendalam sehingga proses transfer informasi antarkelompok semakin masif. Tidak ada mahasiswa yang datang terlambat atau mengeluh tidak dapat mengakses informasi karena tidak ada laptop atau jaringan internet. Di siklus II, mahasiswa telah terbiasa dengan fase-fase pembelajaran Jigsaw sehingga pembelajaran berjalan dengan lebih lancar. Berdasarkan hasil posttest II, diperoleh fakta bahwa banyaknya mahasiswa yang memperoleh nilai minimal B melampaui 
$80 \%$, sehingga hasil siklus II tersebut telah memenuhi target indikator keberhasilan penelitian tindakan kelas.

\section{Kesimpulan}

Penelitian ini membawa dampak perbaikan yang dirasakan baik oleh peneliti sebagai pengampu maupun mahasiswa dalam praktik perkuliahan Analisis Kurikulum Matematika SMP. Peneliti tidak hanya merasakan kendala yang harus diperbaiki dalam pembelajaran, melainkan juga manfaat yang dapat diperoleh dengan adanya peningkatan pemahaman konsep mahasiswa pada materi matematika SMP. Peneliti menarik kesimpulan sebagai berikut.

(1) Penerapan model pembelajaran kooperatif tipe Jigsaw membutuhkan alokasi waktu perkuliahan yang cukup lama. Satu kali siklus Jigsaw dapat dilaksanakan dalam satu atau lebih pertemuan.

(2) Mahasiswa perlu mendapatkan sesi penjelasan khusus mengenai aturan main dan tahapan-tahapan pembelajaran dengan menggunakan model Jigsaw.

(3) Dukungan laptop, gawai, dan internet untuk mengeksplorasi materi sangat dibutuhkan dalam pembelajaran.

(4) Diskusi kelompok perlu dikemas dengan menarik, tidak monoton, sehingga keterlibatan mahasiswa dalam aktivitas pembelajaran lebih tinggi, salah satunya dengan menerapkan game tanya jawab.

(5) Pembelajaran kooperatif tipe Jigsaw dapat mengkondisikan mahasiswa untuk aktif mencari informasi dan menyampaikannya kepada teman secara kolaboratif sehingga mempermudah proses transfer informasi.

(6) Pembelajaran kooperatif tipe Jigsaw dapat meningkatkan kemampuan pemahaman konsep mahasiswa terhadap materi matematika SMP.

\section{Ucapan Terimakasih}

Penulis mengucapkan terima kasih kepada Universitas Ahmad Dahlan atas kesempatan melakukan penelitian dengan dana internal.

\section{Pustaka}

Amir, A. 2013. Pengembangan Profesionalisme Guru dalam Pembelajaran melalui Model Lesson Study. Logaritma, 1(2): 130-143.

Arifin, Z. 2009. Membangun Kompetensi Pedagogis Guru Matematika: Landasan Filosofi, Histori, dan Psikologi. Surabaya: Lentera Cendikia.

Arikunto, S. 2006. Penelitian Tindakan Kelas. Jakarta: Bumi Aksara.

Meningkatkan... (Vita Istihapsari) 
Arikunto, S. 2009. Dasar-dasar Evaluasi Pendidikan (Edisi Revisi). Jakarta: Bumi Aksara.

Jalal, F. 2007. Sertifikasi Guru untuk Mewujudkan Pendidikan yang Bermutu. Medan: Universitas Negeri Medan.

Karacop, A. 2017. The effects of using Jigsaw Method based on cooperative learning model in the undergraduate laboratory practices. Universal Journal of Educational Research, 5(3): 420-434.

Kordaki, M., \& Siempos, H. 2010. The Jigsaw Collaborative Method within Online Computer Classroom. Proceeding of the $2^{\text {nd }}$ International Conference on Computer Supported Education. Tersedia di: https://pdfs.semanticscholar.org/5a0a 1597ad966d3900d331cf4b9d4b88b16 d5f812.pdf.

Kunandar. 2007. Guru Profesional Implementasi Kurikulum Tingkat Satuan Pendidikan (KTSP) dan Sukses dalam Sertifikasi Guru. Jakarta: Rajagrafindo Persada.

Long, C. 2005. Maths concepts in teaching: Procedural and conceptual knowledge. Pythagoras, 62: 59-65.

OECD. 2013. PISA 2012 Assessment and Analytical Framework: Mathematics, Reading, Science, Problem Solving and Financial Literacy. OECD Publishing. Tersedia di: http://dx.doi.org/10.1787/978926419 0511-en [diakses pada 31 Desember 2016].
Palincsar, A.S. \& Brown A.L. 1984. Reciprocal Teaching of Comprehension-Fostering and Comprehension-Monitoring Activities, Cognition and Instruction, 1(2):117-175.

Prawiradilaga, D.S. 2007. Prinsip Disain Pembelajaran. Jakarta: Kencana.

Prihandoko, A.C. 2005. Memahami Konsep Matematika Secara Benar dan Menyajikannya dengan Menarik. Jakarta: Depdiknas.

Sierpinska, A. 1990. Some Remarks on Understanding in Mathematics. For the Learning of Mathematics, 10(3): 24-36.

Wardhani, S. 2008. Analisis SI dan SKL Mata Pelajaran Matematika SMP/MTs untuk Optimalisasi Pencapaian Tujuan. Yogyakarta: P4TK.

Widhyantini. 2006. Model Pembelajaran Matematika dengan Pendekatan Kooperatif. Yogyakarta: P3GMAT Yogyakarta 